\title{
Corporate Social Responsibility as a Mediator of the Effect of Brand Awareness and Corporate Reputation on Customer Loyalty
}

Lovemore Chikazhe, Blessing Chigunha, Martin Dandira

Chinhoyi University of Technology, Zimbabwe

Tendai Silvaziso Mandere, King Christopher Muchenje

Ba Isago University, Botswana

Received: June 3, 2020 Accepted: June 18, 2020 Published: June 27, 2020

doi:10.5296/bms.v11i1.17141ＵRL: https://doi.org/10.5296/bms.v11i1.17141

\begin{abstract}
Factors that promote customer loyalty are of great concern to the banking sector because loyalty predicts business success. The purpose of this study is to examine the mediation role of corporate social responsibility on the effect of brand awareness and corporate reputation on customer loyalty. Data was collected through a cross sectional survey from 405 bank customers. Research hypotheses were tested using the structural equation model. The findings show that corporate social responsibility partially mediates the effect of both brand awareness and corporate reputation on customer loyalty. The results indicate that corporate social responsibility plays a vital role within the banking sector as it mediates the effect of brand awareness and corporate reputation on customer loyalty. If banks engage in successful corporate social responsibility practices, brand awareness and corporate reputation are enhanced and this result in improved customer loyalty. By empirically examining corporate social responsibility as a mediator on the effect of brand awareness and corporate reputation on customer loyalty the study seeks to contribute to the scholarly conversation.
\end{abstract}

Keywords: Banking Sector, Brand Awareness, Corporate Reputation, Corporate Social Responsibility, Customer Loyalty

\section{Introduction}

The banking sector is experiencing massive changes due to economic liberalisation in most 
economies. The emergence of more players into the sector has increased competition (Hafez, 2018; Pratihari and Uzma, 2018). Banks are faced with a mammoth task of offering better services and introducing competitive products to satisfy and retain various types of customers. The arrival of more banks is exerting tremendous pressure to the banking community on how to handle customer expectations and changing demands (Arcand, PromTep, Brun \& Rajaobelina, 2017). Currently, banks depend on retaining existing customers than attracting new ones (Pratihari \&Uzma 2018; Saleem, Zahra, Ahmad, \&Ismail 2016). The availability of more players providing related products is giving customers the opportunity to switch service providers depending on which banking institution is able to meet their expectations (Makanyeza \& Chikazhe, 2017).

Competition has reached a point where banks' survival is now dependent on the improvement of corporate social responsibility practices, brand awareness, firm reputation as well as customer retention programmes. The major challenge is on how to retain customers and increase the market share. Banks are expected to employ survival strategies that provide them with a competitive advantage. In so doing, banks need to retain and reach more customers through programmes like corporate social responsibility (Abratt \& Russell, 1999; Konalingam et al., 2017).

Despite the fact that the majority of banks are involved in programmes to do with customer care, more effort is needed to ensure customer loyalty (Gurlek et al., 2017; Riasi, 2015). With loyal customers, banks can maximise profits as loyal customers make repeat purchases. Furthermore, loyal customers recommend the firm's products and services to friends and give organisations genuine suggestions (Harjoto \& Salas, 2017). Banking professionals must therefore continue to seek out most influential determinants of customer loyalty.

The marketing literature is awash with studies that have examined the relationship among corporate social responsibility, brand awareness, corporate reputation and customer loyalty (Amin et al., 2013; Greve, 2014; Hafeez \& Muhammad 2012; Lee et al., 2017; Saleem et al., 2016). Despite the effort by previous researchers to address the loyalty challenge within the banking sector, no study has focussed on the mediation role of corporate social responsibility on the effect of brand awareness and corporate reputation on customer loyalty. This study contributes to the management's body of knowledge by examining the mediation role of corporate social responsibility on the effect of brand awareness and corporate reputation on customer loyalty.

\section{Literature Review}

\subsection{Customer Loyalty}

Customer loyalty is understood as the customer's predisposition and intention to buy from the same company and this results from the view that the value received from the same firm is superior than the value offered from alternatives (Berg, 2008; Gurlek et al., 2017; Hafez, 2018). Similarly, Paulssen, Roulet and Wilke (2014) added that customer loyalty is determined by feelings that motivate a general attachment to the people, services or products 
of a company. Also, customer loyalty comprises psychological relationship centred on behavioural element, based on aspects like the frequency of visits to a company (Arli \& Lasmono, 2010; Kocoglu and Kirmaci, 2012).

Customer loyalty is also understood to be a combination of consumers' behaviour and attitude (Akbari et al., 2019; Dick \& Basu, 1994; Pratihari, \& Uzma, 2018). Dick \& Basu (1994) defines attitudinal loyalty as the psychological and emotional state of the customer to repurchase and to recommend products and services to other customers. Behavioural loyalty is the customers' behaviour to repurchase as a result of the liking of a particular product, service or brand (Akbari et al., 2019). Attitudinal loyalty is used to comprehend how customers feel about the firms' brand and products or services. Behavioural loyalty measures if customers are acting on their feelings of loyalty (Pratihari \& Uzma, 2018). Dahlstrom et al., (2014) proclaimed that behavioural loyalty may be measured using transactional and sales data. Therefore, organisations are encouraged to focus more on attitudinal and behavioural loyalty as they both drive company success and sustainability (Jarvinen, 2014; Lee et al., 2017). Moreover, customer loyalty benefits organisation in that loyal and satisfied customers recommend products and services to others and continue to purchase from the same firm (Akbari et al., 2019). If an organisation fails to pay attention to the loyalty concept, customers are likely to defect to competitors that offer better products and services.

\subsection{Brand Awareness}

Brand of a product refers to intangible aspects like names, price, packaging and the image portrayed within the market (Harjoto \& Salas, 2017; Iglesias et al., 2011). Lee and Kotler (2009) describes brand awareness as the differential effect that comes from consumers' response to products and services that result from knowing the brand name. Additionally, Arcand \& PromTep (2016) described brand awareness as the level of customer perception of a company. Furthermore, Alamro and Rowley (2011) explains a brand as customer's opinions on a service or product based from their own experience.

Brand awareness is vital to organisations especially when they launch new products (Gurlek et al., 2017). Branding drives consumers to distinguish products for competing organisation (Bloemer et al., 1998; Greve, 2014). If consumers enjoy the firm's products and services, repeat purchases are realised and market share is increased (Harjoto \& Salas, 2017). Tingchi et al. (2014) emphasised that a brand should provide assurance of worth that help consumers in recognising a branded product much easier than a non-branded one. Brands measure a potential consumer's ability to not only identify a brand image, but to also relate it with a certain firm's service or product (Amini \& Ahmadinejad, 2012). Brands are used for products and service identification and to differentiate the firm's products and service from those of competitors (Greve, 2014). In this modern epoch, firms are undertaking marketing practices such as brand awareness with the aim of putting themselves on the map and differentiating themselves from competitors (Hafeez \& Muhammad, 2012).

Brand awareness has gained popularity since it is the most prized possession any firm can 
own (Kocoglu \& Kirmaci, 2012). Organisation should protect and enhance their brands such that they gain competitive advantage (Anwar, Gulzar, Sohail \& Akram, 2011). Organisations are encouraged to put more effort towards the improvement of brand awareness as this is the only way to grow business. Some organisations create brand awareness through giving back to the community in which they operate. The brand knowledge is vital to an organisation as it positively effect customers' response to products, prices, communications, channels and other marketing activity (Bloemer et al., 1998; Kocoglu \& Kirmaci, 2012). Brand awareness may be initiated by the firm's involvement in activities like; hosting educational and social events, being the trusted expert, sharing gratitude, organising service projects and being a helpful friend (Davijani, Nouri \& Horri, 2015). Therefore, corporate social responsibility plays an important role in creating band awareness (Anwar et al, 2010; Davijani et al., 2015).

\subsection{Corporate Reputation}

Corporate reputation is defined as the impression made by customers about an organisation (Sheita, 2019). The past actions and future predictions of the organisation determine its corporate reputation (Dowling, 2004). Similarly, Walker (2010) claim that corporate reputation has much to do with the overall evaluation in which an organisation held by its customers based on its past actions and probability of its future conduct. Corporate reputation is regarded as a general assessment in a customer's mind towards a firm. Carroll (1999) added that corporate reputation is a mental image which consumers have in mind towards a firm. Corporate reputation is a result of an evaluation of feelings, attitudes and experiences retrieved from customer's memory to create a corporate image towards a firm (Barnett et al., 2006; Karem Kolkailah, Abou Aish \& El-Bassiouny 2012).

Corporate reputation is a vital component of the business that determine the kinds of perceptions customers will have about its history, brand and its potential to survive in future (Mattera et al., 2014). Organisations should ensure that they maintain good reputation so that they gain value on the market and remain successful. Most firms rely on corporate reputation to record their presence on the market. Customer preferences change as they associate with companies with good corporate reputation (M'zungu, Bill \& Miller, 2010). If companies maintain good reputation, chances are high that services and products will perform well as more customers would want to be associated with firms (Kumaradeepan, \& Pathmini, 2017; Hillenbrand \& Kevin, 2007). Customers have a habit of extending their utmost support to firms that show good corporate reputation during tough times. Therefore, corporate reputation is influenced by the firm's involvement in the community activities. Customers are also loyal to companies with good reputation and this is shown by repeated purchases. Mattera et al. (2014) maintain that corporate reputation and expectations affect customer loyalty through the nature and quality of a company's products and services. Corporate reputation is an attitude that posively impacts on the behaviour and intentions affecting customer satisfaction and loyalty (Dick \& Basu, 1994). Carroll (1999) claims that corporate reputation is derived from customer perceptions about the organisation's capability and social responsibility. Moreover, corporate reputation refers to the business' capability in providing 
product and service offerings such as effective innovation and superior service quality, while corporate social responsibility focuses more on the firm's management of social issues.

\subsection{Corporate Social Responsibility}

Corporate social responsibility is described as how firms manage their business to come up with overall positive impact on the community (Bloemer et al., 2014; Kramer \& Porter, 2011; Kouatli, 2018). Similarly, Adamson, Kok-Mun Chan \& Donna Handford (2003) explain corporate social responsibility as the obligations of the business to people within the society or more specifically to those affected by the business policies and practices. The corporate social responsibility depends on how businesses are sanctioned and promoted by their community (Henrique \& De Matos, 2015; Liu et al., 2014; Quazi, Amran \& Nejati, 2016). The society expect firms operating within their environment to be good corporate citizens. Moreover, businesses have an obligation to act for the social good of the community (Arcand \& PromTep, 2016; Raizada, 2016). As such, businesses should not aim at making profits only, but to play a helping role in finding solutions to problems that affect the society in which they operate (Amin, 2016; Hustvedt and Bernard, 2010; Lai et al., 2010). Businesses operating within a community are expected to be involved in developmental activities that improve the infrastructure and the society's welfare (Lee et al., 2017). Most businesses excel because they plough back part of their proceeds to the society (Marin Ruiz \& Rubio, 2009; Uduji \& Okolo-Obasi, 2019). Firms that fail to meet the society's expectations also find it difficult to attract and retain customers from the surrounding community (Aggarwal and Singh, 2019; Cha, Abebe, \& Dadanlar, 2019; Trini, \& Salim, 2018). Thus, if corporates wish to be viable in the long run, they should respond to needs of the society through involvement in philanthropic programmes (Ahen \& Amankwah-Amoah, 2018; Fatma, Khan, \& Rahman, 2019). Moreover, businesses are citizens within a society, hence citizens have civic duties and responsibilities which they must discharge voluntarily (Dimitropoulos \& Vrondou, 2015; Saleem et al., 2016). Caruana \& Calleya (1998) stress that businesses have a huge pool of resources like human resource, money, talents functional and professional expertise that better position them to work for social goals.

\section{Development of Research Hypotheses and Research Model}

Previous studies confirm the presence of relationships among corporate social responsibility, brand awareness and customer loyalty (Aggarwal and Singh, 2019; Arcand et al., 2017; Arikan, 2016; Cha et al., 2019; Gurlek et al., 2017; Hea \& Laib, 2014; Harjoto \& Salas, 2017; Lee et al., 2017). Choi \& La (2013) examined corporate social responsibility and focussed on related constructs such as customer loyalty, customer satisfaction and customer trust. The study results indicate that corporate social responsibility impacts positively on customer loyalty and customer trust. Similarly, Gurlek et al. (2017) investigated the relationship among corporate image, corporate social responsibility and customer loyalty in a hotel setup. Findings show that corporate social responsibility influences customer loyalty and corporate image. Equally, Hea \& Laib (2014) studied how corporate social responsibility affects brand loyalty as well as brand image. The study results specify that consumers' perceived that 
lawful and moral responsibilities improve brand loyalty through enhancing positive functional and symbolic images which also improves customer loyalty. Lee et al. (2017) investigated how corporate social responsibility impacts on customer loyalty and corporate reputation. Results demonstrate that corporate social responsibility positively influences customer loyalty and corporate reputation. However, there is missing evidence in the public domain as regards the mediating role of corporate social responsibility on the effect of brand awareness on customer loyalty, especially within the banking sector. Therefore, it is hypothesised that,

$H_{1}$ : Corporate Social Responsibility mediates the effect of brand awareness on customer loyalty

Literature is awash with evidence that there is a positive relationship among corporate social responsibility, corporate reputation and customer loyalty (Abd-El-Salam et al., 2013; Ahen \& Amankwah-Amoah, 2018; Akbari et al., 2019; Hillenbrand \& Kevin 2007; Lai et al., 2010; Lee et al., 2017; Pratihari \& Uzma, 2018; Tingchi et al. 2014). Abd-El-Salam et al. (2013) explored the association among corporate reputation and image, customer satisfaction, service quality and customer loyalty through a case analysis on one of the biggest Egyptian company. The study results show significant relationships among all variables investigated. Similarly, Lee et al. (2017) investigated how corporate social responsibility influences corporate reputation and customer loyalty. The results confirmed that corporate social responsibility undertakings have significant influence on corporate reputation and customer loyalty. Additionally, it was established that corporate social responsibility activities have a positive influence on brand image. Likewise, Lai et al. (2010) studied the effects of corporate social responsibility on brand performance paying attention to the mediating effect of brand loyalty and corporate reputation. The results show that corporate social responsibility positively impacts on the relationship among corporate reputation, loyalty, industrial brand equity and brand performance. Thus, the mediation role of corporate social responsibility on the effect of corporate reputation on customer loyalty is not documented in the public domain. It is therefore hypothesised that,

$\mathrm{H}_{2}$ : Corporate social responsibility mediates the effect of corporate reputation on customer loyalty

Considering the preceding hypotheses, the following research model is proposed; - 


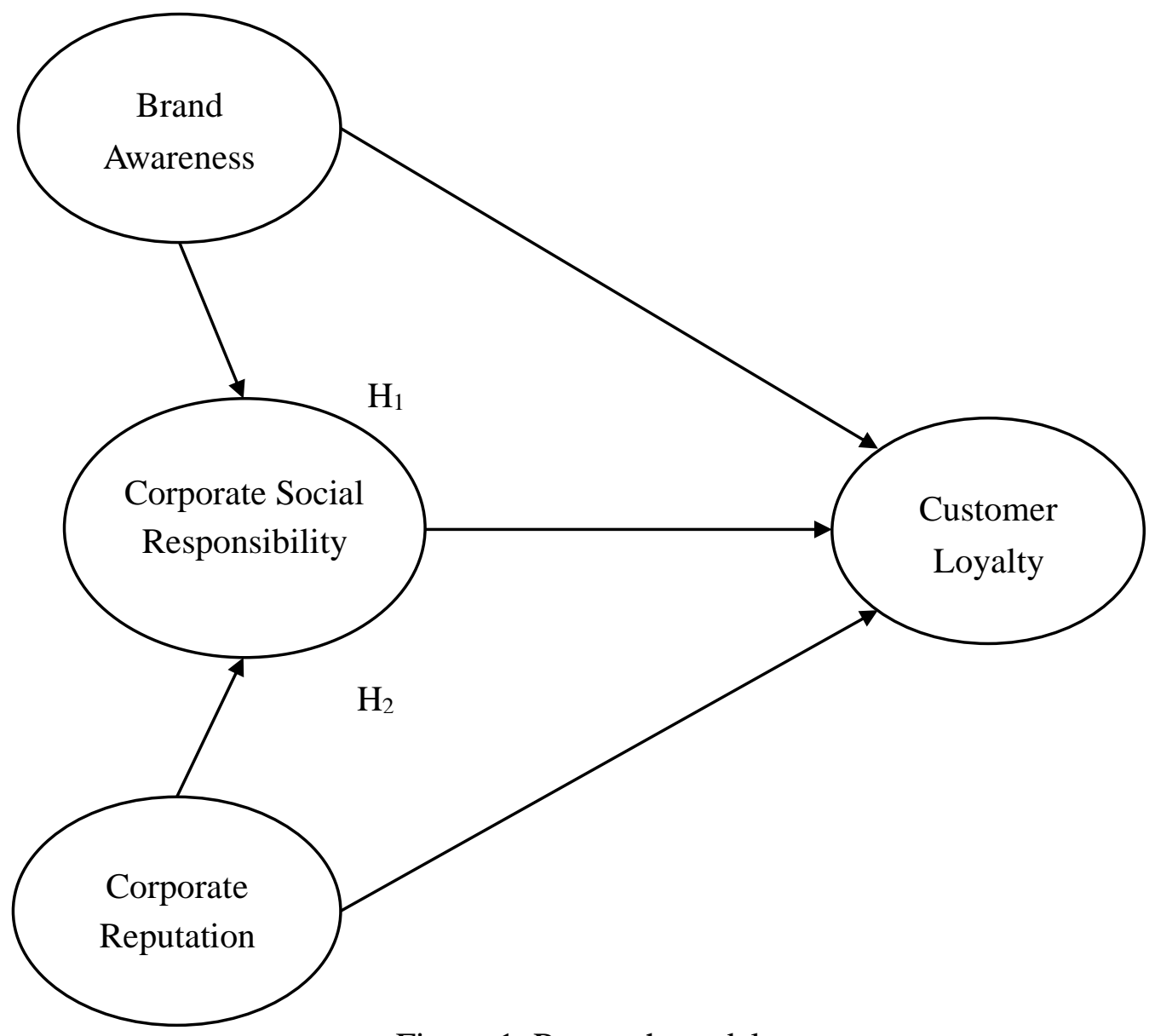

Figure 1. Research model

\section{Research Methodology}

The research methodology focuses on questionnaire design and measures, sampling and data collection methods.

\subsection{Sample and Data Collection}

The proposed model for this study was tested in the context of the banking sector. It is worth revealing that the banking sector in Zimbabwe has become proactively engaged in corporate social responsibility initiatives and investing significantly in various programmes.

Survey data were collected through personal survey from bank customers in Chinhoyi, Zimbabwe in March 2020. Chinhoyi was chosen because of its representation for many banks that operate within Zimbabwe. Questionnaires were personally distributed to customers who visited their banks during the period under which data collection was in process. Out of the 450 randomly distributed questionnaires, 405 were returned and usable. The study opted for a larger sample so as to cater for more customers from various banks. Response rate was $90 \%$, 


\section{Macrothink}

Business Management and Strategy

ISSN 2157-6068

2020, Vol. 11, No. 1

with males contributing $57 \%$ of the respondents and females constituting $43 \%$. The age for the respondents ranged from 16 to 46 and above. Customers aged between 16 to 35 were more than all other ranges with $54 \%$, followed by those between 36 and 45 who constituted $31 \%$. The remainder $(15 \%)$ were above 46 years. The time of residence in the community of which respondents were able to deal with banks within the area ranged from 5 to 21 years and above. The majority (75\%) of the bank customers had stayed within the same community for more than 16 years. This information was important for the study as it indicate that respondents had experience on banks' involvement within the community.

\subsection{Questionnaire Design and Measures}

A questionnaire survey was used to obtain measures of corporate social responsibility (CSR), customer loyalty (CL), corporate reputation (CR) and brand awareness (BRA). All items under each concept were measured using a Likert scale that ranged from 1 (Strongly disagree) to 5 (Strongly agree). Items under each construct were borrowed from previous related studies (Encinas Orozco et al., 2017; Chandra et al. 2018; Makanyeza \& Chikazhe, 2017; Gurlek et al., 2017; Lee et al., 2017; Lai et al., 2010; Ng. 2018) and they were modified to suit the current study. The items for CSR, CL, CR and BRA focused on perceptions of banking customers in Zimbabwe.

\section{Analysis and Results}

\subsection{Scale Validation}

Measurement model was validated before the structural model was performed. Thus, convergent validity, exploratory factor analysis and discriminant validity were performed before structural equation modelling was conducted. Data analysis was conducted using SPSS version 21 and AMOS version 21. Kaiser-Meyer Olkin (KMO) measure and Bartlett's Test of Sphericity were used to determine the sample adequacy. Results are presented in Table 1 below:

Table 1. KMO and Bartlett's Test

\begin{tabular}{|l|l|r|}
\hline \multicolumn{2}{|c|}{ KMO and Bartlett's Test } \\
\hline Kaiser-Meyer-Olkin Measure of Sampling Adequacy. & .835 \\
\hline \multirow{2}{*}{ Bartlett's Test of Sphericity } & Approx. Chi-Square & 14985.127 \\
\cline { 2 - 3 } & df & 490 \\
\cline { 2 - 3 } & Sig. & .000 \\
\hline
\end{tabular}


The results in Table 1 confirm that it was possible to perform exploratory factor analysis since they satisfied Minimum conditions. Results met minimum conditions as recommended that Bartlett's Test of Sphericity value is significant at $p<0.000$ and that Kaiser-Meyer-Olkin value must be above 0.6 (Bartlett, 1954; Kaiser, 1974). Factor analysis was performed through Varimax Rotation and it converged in 9 iterations. The results indicate that total variance explained by the data was $95.664 \%$.

Convergent validity was evaluated using the measurement model fit indices, standardised factor loadings, critical ratios, reliability and average variance extracted (AVE). The study results submit that convergent validity conditions were satisfied. The measurement model fit indices measured are presented in Table 2 below:

Table 2. Measurement model fit indices

\begin{tabular}{|c|c|c|c|}
\hline $\begin{array}{c}\text { Fit } \\
\text { index }\end{array}$ & $\begin{array}{c}\text { Measurement } \\
\text { model }\end{array}$ & $\begin{array}{c}\text { Recommended } \\
\text { level }\end{array}$ & Source \\
\hline CMIN/DF ( $\chi 2 / D F)$, & 2.452 & $<5$ & \multirow{7}{*}{$\begin{array}{l}\text { Hair et al. (2006), } \\
\text { Bagozzi \& Yi (1988), } \\
\text { McDonald \& Ho (2002), } \\
\text { Kline (2015), } \\
\text { Fornell \& Larcker (1981), } \\
\text { Reisinger \& Mavondo, 2007, } \\
\text { Hooper et al., } 2008\end{array}$} \\
\hline GFI & 0.925 & $>0.900$ & \\
\hline AGFI & 0.921 & $>0.900$ & \\
\hline NFI & 0.912 & $>0.900$ & \\
\hline TLI & 0.921 & $>0.900$ & \\
\hline CFI & 0.919 & $>0.900$ & \\
\hline RMSEA & 0.035 & $<0.080$ & \\
\hline
\end{tabular}

As stated in Table 3, all calculated figures were above the commended levels (Hair et al., 2006). All constructs had composite reliabilities (CRel) and Cronbach's alpha $(\alpha)$ of above 0.6 (McDonald \& Ho., 2002). All items indicate standardised factor loadings $(\lambda)$ above the 0.6 (Hair et al., 2006). Critical ratios were big enough and significant at $\mathrm{p}<0.001$. All individual item reliabilities (IIRs) were at least 0.5 (Kline, 2015). All constructs had averages larger than 0.5 as shown in Table 4 (Hooper et al., 2008). 
Table 3. Standardised Factor Loadings $(\lambda)$, Individual Item Reliabilities (IIRs), Critical ratios (CRs), Cronbach's alpha $(\alpha)$ and Composite Reliability (CRel)

\begin{tabular}{|c|c|c|c|c|c|c|}
\hline Constructs & Items & $\lambda$ & IIR & CR & $\alpha$ & CRel \\
\hline \multirow{4}{*}{$\begin{array}{l}\text { Corporate } \\
\text { social } \\
\text { responsibility }\end{array}$} & CSR1 & .714 & .658 & - & \multirow[t]{3}{*}{.901} & \multirow[t]{3}{*}{.975} \\
\hline & CSR2 & .798 & .736 & $22.745^{* * *}$ & & \\
\hline & CSR3 & .896 & .885 & $14.285^{* * *}$ & & \\
\hline & CSR4 & .874 & .878 & $15.675^{* * *}$ & & \\
\hline \multirow{5}{*}{$\begin{array}{l}\text { Customer } \\
\text { loyalty }\end{array}$} & CL1 & .756 & .679 & - & \multirow[t]{4}{*}{.895} & \multirow[t]{4}{*}{.925} \\
\hline & CL2 & .821 & .774 & $14.895^{* * * *}$ & & \\
\hline & CL3 & .863 & .879 & $23.789^{* * * *}$ & & \\
\hline & CL4 & .814 & .875 & $14.645^{* * *}$ & & \\
\hline & CL5 & .874 & .798 & $15.231^{* * *}$ & & \\
\hline \multirow{5}{*}{$\begin{array}{l}\text { Corporate } \\
\text { reputation }\end{array}$} & CR1 & .865 & .741 & - & \multirow[t]{4}{*}{.875} & \multirow[t]{4}{*}{.942} \\
\hline & CR2 & .854 & .709 & $16.465^{* * *}$ & & \\
\hline & CR3 & .896 & .708 & $17.002^{* * *}$ & & \\
\hline & CR4 & .852 & .702 & $34.255^{* * *}$ & & \\
\hline & CR5 & .795 & .745 & $13.995^{* * * *}$ & & \\
\hline \multirow{5}{*}{$\begin{array}{l}\text { Brand } \\
\text { awareness }\end{array}$} & BRA1 & .745 & .789 & - & \multirow[t]{5}{*}{.862} & \multirow[t]{5}{*}{.884} \\
\hline & BRA2 & .759 & .697 & $16.744^{* * *}$ & & \\
\hline & BRA3 & .847 & .778 & $15.243^{* * *}$ & & \\
\hline & BRA4 & .879 & .788 & $12.322^{* * * *}$ & & \\
\hline & BRA5 & .798 & .792 & $21.213^{* * * *}$ & & \\
\hline
\end{tabular}

Note: - CR is fixed; ${ }^{* * *} \mathrm{p}<0.001$

\subsection{Discriminant Validity}

Discriminant validity was obtained by confirming that all averages were higher than their corresponding squared inter construct correlations (SICCs) (Hair et al., 2006). Table 4 below, 
indicate that minimum conditions for discriminant validity were fulfilled.

Table 4. Mean (M), standard deviation (SD), AVE and SICC

\begin{tabular}{|l|c|c|c|c|c|c|}
\hline Construct & Mean & $\begin{array}{c}\text { Standard } \\
\text { Deviation }\end{array}$ & CSR & CL & CR & BRA \\
\hline Corporate social responsibility & 4.214 & 1.254 & $\mathbf{. 8 9 6}$ & & & \\
\hline Customer loyalty & 5.006 & 1.012 & .433 & $\mathbf{. 7 8 4}$ & & \\
\hline Corporate reputation & 4.645 & 1.214 & .338 & .488 & $\mathbf{. 7 6 5}$ & \\
\hline Brand awareness & 4.824 & 1.402 & .512 & .430 & .490 & $\mathbf{. 8 3 5}$ \\
\hline
\end{tabular}

Note: Diagonal elements in bold represent AVEs

\subsection{Hypotheses Tests}

This study tested hypotheses $\mathrm{H}_{1}$ and $\mathrm{H}_{2}$ using Structural Equation Modelling in AMOS. Structural modelling technique was used to test hypotheses because it is able to decide relationships while establishing whether or not there is a general fit between the research model and observed data (Hooper et al., 2008).

The results in Table 5 show that fit indices of the structural model were satisfactory as shown below:

Table 5. Structural model fit indices

\begin{tabular}{|c|c|c|c|}
\hline $\begin{array}{c}\text { Fit } \\
\text { index }\end{array}$ & $\begin{array}{c}\text { Measurement } \\
\text { model }\end{array}$ & $\begin{array}{c}\text { Recommended } \\
\text { level }\end{array}$ & Source \\
\hline CMIN/DF $\left(\chi^{2 / D F}\right)$, & 2.536 & $<5$ & \multirow{7}{*}{$\begin{array}{l}\text { Fornell \& Larcker (1981), } \\
\text { Hooper et al. (2008) } \\
\text { Hair et al. (2006), } \\
\text { Kline (2015), } \\
\text { Bagozzi \& Yi (1988), } \\
\text { McDonald \& Ho (2002), } \\
\text { Reisinger \& Mavondo, (2007) }\end{array}$} \\
\hline GFI & 0.915 & $>0.900$ & \\
\hline AGFI & 0.927 & $>0.900$ & \\
\hline NFI & 0.902 & $>0.900$ & \\
\hline TLI & 0.910 & $>0.900$ & \\
\hline CFI & 0.922 & $>0.900$ & \\
\hline RMSEA & 0.038 & $<0.080$ & \\
\hline
\end{tabular}




\section{Macrothink}

As summarised in Table 5, all fit indices for the research model were satisfactory. Results for hypotheses tests are presented in Table 6 below:

Table 6. Hypothesis test results

\begin{tabular}{|c|c|c|c|c|}
\hline $\begin{array}{l}\text { Hypo } \\
\text { thesis }\end{array}$ & Path & $\begin{array}{c}\text { Path } \\
\text { Coefficient }\end{array}$ & Description & Comments \\
\hline $\mathbf{H}_{1}$ & $\mathrm{BRA} \longrightarrow \mathrm{CSR}$ & $0.314^{* * *}$ & CSR partially mediates the effect of BRA on CL & $\mathrm{H}_{1}$ is supported \\
\hline $\mathbf{H}_{2}$ & $\mathrm{CR} \longrightarrow \mathrm{CRS} \longrightarrow \mathrm{CL}$ & $0.439^{* * * *}$ & CSR partially mediates the effect of CR on CL & $\mathrm{H}_{2}$ is supported \\
\hline
\end{tabular}

Note: $* * *$ Significant at $\mathrm{p}<0.001$

Results in Table 6 show that corporate social responsibility partially mediates the effect of both brand awareness and corporate reputation on customer loyalty. Thus, both $\mathrm{H}_{1}$ and $\mathrm{H}_{2}$ were supported.

\section{Discussion and Implications}

\subsection{Theoretical Implications}

Regardless of previous studies that have examined the relationship among corporate social responsibility, brand awareness, corporate reputation and customer loyalty within the banking sector (Arikan, 2016; Bloemer et al., 2014; Gurlek et al., 2017; Hea \& Laib, 2014; Kramer \& Porter, 2011; Kouatli, 2018; Lee et al., 2017) empirical evidence is still dividend. The current study provides evidence that corporate social responsibility mediates the effect of both brand awareness and corporate reputation on customer loyalty within the banking sector.

The study established that corporate social responsibility partially mediates the effect of brand awareness on customer loyalty. The results imply that corporate social responsibility plays a central role on the relationship between brand awareness and customer loyalty. Thus, banks should improve their involvement in sponsoring and funding community programmes if they are to market their brands to the same community. Customers familiarise with brands, products and service from organisations that plough back proceeds to the community. Through corporate social responsibility practice, banks are able to grow their market share and grow business. Competitive advantage is one other benefit for banks that are involved in corporate social responsibility since customers are likely to choose their brands ahead of those for competitors. Results of the study proved that brand awareness is enhanced through 
corporate social responsibility activities which results in the growth of a strong base of loyal customers.

The results of the study also approved that corporate social responsibility partially mediates the effect of corporate reputation on customer loyalty. Results imply that corporate social responsibility plays a critical role on the relationship between corporate reputation and customer loyalty. Banks should strive to maintain a good name to customers as this is one way to improve customer loyalty. Customers are loyal to service providers that are reputable. Corporate social responsibility plays an important role as it preaches more about the company's name. Customers get to know most organisations and become loyal to them through philanthropic activities carried out within the community. If banks need to gain reputation, they should improve their image through ethical business conduct within the community. Banks should show that they care for the community through sponsoring programmes to do with the welfare of the people within the society. Banks should improve their reputation by being sensitive to programmes that promote a health environment for the community. Corporate social responsibility activities like sponsorship and donations may improve banks' reputation resulting in increased customer loyalty. Thus, the findings of the current study contribute to management body of knowledge.

\subsection{Practical Implications}

It is urgent however in the Zimbabwean context that the banking sector understand that they have a social responsibility to undertake so as to improve customer loyalty. Banks should invite the community authorities like local authorities to provide them with their yearly plans so that bank management selects programmes to partner through sponsorships and donations. In doing so, banks will be able to promote their brands as well as enhance company reputation. Additionally, corporate social responsibility-based multi-stakeholder conglomerates may be rewarding in economic, social and environmental challenges in Zimbabwe and other developing economies. Thus, the brand awareness and corporate reputation framework of any bank must exhibit some degree of good corporate social responsibility so as to influence customer loyalty. Besides a short history of corporate social responsibility in Zimbabwe, banks should strive to improve community involvement as this is one way to reach new customers

\section{Further Research Implications}

The current study used perceptions of bank customers only. Future studies intending to consider topics related to the mediating role of corporate social responsibility on the effect of brand awareness and corporate reputation on customer loyalty may consider bank employee perceptions. Future studies may also use demographic data like gender, age, employment type and income as moderators of the current study relationships. This may improve results of the current study. 


\section{References}

Abd-El-Salam, E. M. Shawky, A. Y. \& El-Nahas, T. (2013). The impact of corporate image and reputation on service quality, customer satisfaction and customer loyalty: testing the mediating role. Case analysis in an international service company. The Business \& Management Review. (3)2.

Abratt, R. \& Russell, J. (1999). Relationship marketing in private banking in South Africa. International of Journal Bank Marketing. https://doi.org/10.1108/02652329910254000

Adamson, I., Chan, K.M. \& Handford, D. (2003). Relationship marketing: customer commitment and trust as a strategy for the smaller Hong Kong corporate banking sector. International journal of bank marketing. https://doi.org/10.1108/02652320310498492

Aggarwal, P. \& Singh, A.K. (2019). CSR and sustainability reporting practices in India: an in-depth content analysis of top-listed companies. Social Responsibility Journal. https://doi.org/10.1108/SRJ-03-2018-0078

Ahen, F. \& Amankwah-Amoah, J., (2018). Institutional voids and the philanthropization of CSR practices: Insights from developing economies. Sustainability, 10(7), p.2400. https://doi.org/10.3390/su10072400

Akbari, M., Mehrali, M., SeyyedAmiri, N., Rezaei, N. \& Pourjam, A., (2019). Corporate social responsibility, customer loyalty and brand positioning. Social Responsibility Journal. https://doi.org/10.1108/SRJ-01-2019-0008

Alamro, A. \& Rowley, J. (2011). Brand strategies of Jordanian telecommunications service providers. Journal of Brand Management, 18(4-5), 329-348.

Amin, M., Isa, Z. \& Fontaine, R., (2013). Islamic banks: Contrasting the drivers of customer satisfaction on image, trust and loyalty of Muslim and non-Muslim customers in Malaysia. International Journal of Bank Marketing,31(2), 79-97. https://doi.org/10.1108/02652321311298627

Amini, M. T. \& Ahmadinejad, M. (2012). The role of brand identity, image, loyalty and employee brand in PNU brand strategy. Journal of business and applied scientific research, 2 (10).

Anwar, A. Gulzar, A., Sohail, F. B. \& Akram, S. W. (2011). Impact of brand image, trust on customer brand extension attitude: The mediating role of brand loyalty. International journal of economics and management sciences, 1(5), 73 - 79.

Arcand, M., PromTep, S., Brun, I. \& Rajaobelina, L., (2017). Mobile banking service quality and customer relationships. International Journal of Bank Marketing. https://doi.org/10.1108/IJBM-10-2015-0150

Arikan, E.; Kantur, D.; Maden, C. \& Telci, E. (2016). Investigating the mediating role of 
corporate reputation on the relationship between corporate social responsibility and multiple stakeholder outcomes. Source: Quality \& Quantity. 50(1), 129-149.

Arli, D.I. \& Lasmono, H.K. (2010). Consumers' perception of corporate social responsibility in a developing country. International Journal of Consumer Studies, 34(1), pp.46-51.

Bagozzi, R. P., \& Yi, Y. (1988). On the evaluation of structural equation models. Journal of the Academy of Marketing Science. 16(1), 74-94.

Barnett, Michael L., John M. Jermier, \& Barbara A. Lafferty. (2006). "Corporate reputation: The definitional landscape." Corporate reputation review 9(1) 26-38.

Bartlett MS. (1954). A note on the multiplying factors for various chi square approximations. Journal of the Royal Statistical Society. 296-298.

Berg, L., (2008). Loyalty, naivety and powerlessness among Norwegian retail bank customers. International Journal of Consumer Studies, 32(3), pp.222-232.

Bloemer, J., De Ruyter, K. \& Peeters, P., (1998). Investigating drivers of bank loyalty: the complex relationship between image, service quality and satisfaction. International Journal of bank marketing.

Carroll, A.B. (1999). Corporate social responsibility: Evolution of a definitional construct. Business and Society, 38(3), 268-295.

Caruana, A. and Calleya, P. (1998). The effect of internal marketing on organisational commitment among retail bank managers. International Journal of bank marketing.

Cha, W., Abebe, M. \& Dadanlar, H. (2019). The effect of CEO civic engagement on corporate social and environmental performance. Social Responsibility Journal. https://doi.org/10.1108/SRJ-05-2018-0122

Choi, B. \& La, S. (2013). The impact of corporate social responsibility (CSR) and customer trust on the restoration of loyalty after service failure and recovery. Journal of Services Marketing.

Dahlstrom, R., Nygaard, A., Kimasheva, M. \& Ulvnes, A. M. (2014). How to recover trust in the banking industry? A game theory approach to empirical analyses of bank and corporate customer relationships. International Journal of Bank Marketing, 32(4), 268-278.

Davijani, M. N., Nouri, I., \& Horri, M, S. (2015). Studying the mediating role of customer commitment in the effect of trust, customer satisfaction and social bounds on customer loyalty: A case of Novin Insurance Corporation Iran. International Journal of economics, commerce and management, 3 (9).

Dick, A.S. \& Basu, K. (1994). Customer loyalty: Toward an integrated conceptual framework. Journal of the Academy of Marketing Science, 22(2), 99-113.

Dimitropoulos, P. E., \& Vrondou, O. (2015). Corporate social responsibility and firm value in 
the sport recreation sector: A review. Business Management and Strategy, 6(2), 28-43. URL:http://dx.doi.org/10.5296/bms.v6i2.8542

Dowling, Grahame R. (2004). "Journalists' evaluation of corporate reputations." Corporate Reputation Review 7(2), 196-205.

Encinas Orozco, F. C., \& Cavazos Arroyo, J. (2017). Students' loyalty in higher education: the roles of affective commitment, service co-creation and engagement. Cuadernos de Administración (Universidad del Valle), 33(57), 96-110.

Fatma, M., Khan, I. \& Rahman, Z., (2019). Striving for legitimacy through CSR: an exploration of employee responses in controversial industry sector. Social Responsibility Journal. https://doi.org/10.1108/SRJ-07-2017-0116

Fornell, C., \& Larcker, D. F. (1981). Evaluating structural equation models with unobservable variables and measurement error. Journal of Marketing Research. 18, 39-50. https://doi.org/10.1177/002224378101800104

Greve, G., 2014. The moderating effect of customer engagement on the brand image-brand loyalty relationship. Procedia-Social and Behavioural Sciences, 148, 203-210.

Gürlek, M., Duzgun, E. \& Uygur, S.M. (2017). How does corporate social responsibility create customer loyalty? The role of corporate image. Social Responsibility Journal. 13(9) 3. https://doi.org/10.1108/SRJ-10-2016-0177

Hafeez, S. \& Muhammad, B. (2012). The impact of service quality, customer satisfaction and loyalty programs on customer loyalty: Evidence from banking sector of Pakistan. International journal of business and social service, 3(16).

Hafez, M. (2018). Measuring the impact of corporate social responsibility practices on brand equity in the banking industry in Bangladesh. International Journal of Bank Marketing. https://doi.org/10.1108/IJBM-04-2017-0072

Hair, J. F., Black, W. C., Babin, B. J., \& Anderson, R. E. (2006). Multivariate Data Analysis. Prentice Hall: Upper Saddle River, NJ.

Harjoto, M.A. \& Salas, J. (2017). Strategic and institutional sustainability: corporate social responsibility, brand value, and Inter-brand listing. Journal of Product \& Brand Management. 26(6), 545-558. https://doi.org/10.1108/JPBM-07-2016-1277

Hea, Y, \& Laib, K. K. (2014). The effect of corporate social responsibility on brand loyalty: the mediating role of brand image. Total Quality Management. Vol. 25, No. 3, 249-263.

Henrique, J.L. and De Matos, C.A. (2015). The influence of personal values and demographic variables on customer loyalty in the banking industry. International Journal of bank marketing. https://doi.org/10.1108/IJBM-06-2014-0082

Hillenbrand, C., and Kevin M. (2007). "Corporate responsibility and corporate reputation: 
two separate concepts or two sides of the same coin?" Corporate reputation review 10, no. 4: 261-277

Hooper, D., Coughlan, J. \& Mullen, M. (2008). 'Structural equation modelling: guidelines for determining model fit', Electronic Journal of Business Research Methods. 6 (1), 53-60.

Hustvedt, G. \& Bernard, J.C., (2010). Effects of social responsibility labelling and brand on willingness to pay for apparel. International Journal of Consumer Studies, 34(6), pp.619-626.

Iglesias, O., Singh, J.J., Casabayó, M., Alamro, A. \& Rowley, J. (2011). Antecedents of brand preference for mobile telecommunications services. Journal of Product \& Brand Management. 20(6). https://doi.org/10.1108/10610421111166621

Jarvinen, R. A. (2014). Consumer trust in banking relationships in Europe. International Journal of Bank Marketing, 32(6), 551-566. https://doi.org/10.1108/IJBM-08-2013-0086

Kaiser HF. (1974). An index of factorial simplicity. Psychometrika 39: 31-36.

Karem Kolkailah, S., Abou Aish, E. and El-Bassiouny, N. (2012). The impact of corporate social responsibility initiatives on consumers' behavioural intentions in the Egyptian market. International Journal of Consumer Studies, 36(4), pp.369-384.

Kline, R. B. (2011). Principles and practice of structural equation modeling (3rd ed.). New York, NY: The Guilford Press.

Kline, R. B. (2015). Principles and practice of structural equation modeling. New York, NY: Guilford publications.

Kocoglu, D., Kirmaci, S. (2012). Customer relationship management and customer loyalty: A survey in the sector of banking. International Journal of Business and Social Science, 3(3), 282-291.

Konalingam, K., Ratnam, U., Sivapalan, A., \& Naveen, M. (2017). Enhancing customer loyalty through e-banking practices. Business Management and Strategy, 8 (2), 45, 66. URL:https://doi.org/10.5296/bms.v8i2.12054

Kouatli, I. (2018). The contemporary definition of university social responsibility with quantifiable sustainability. Social Responsibility Journal.

Kramer, M. R. and Porter, M. (2011). Creating shared value. FSG.

Kumaradeepan, V., \& Pathmini, M. G. S. (2017). Customer Satisfaction and Customer Loyalty: Leading Super Markets in Jaffna District, Sri Lanka. Macrothink Institute, 19, 67-75. DOI:10.5296/bms.v8i2.12159

Lai, C.S., Chiu, C.J., Yang, C.F. \& Pai, D.C. (2010). The effects of corporate social responsibility on brand performance: The mediating effect of industrial brand equity and corporate reputation. Journal of business ethics, 95(3), pp.457-469. 
Lee, C. Y., Chang, W.C. \& Lee, H. C. (2017). Corporate reputation and customer loyalty. Evidence from Mandhachitara, R. and Poolthong, Y. (2011). A model of customer loyalty and corporate social responsibility. Journal of Services Marketing, 25(2), 122-133. https://doi.org/10.1108/SRJ-01-2016-0006

Lee, N. R. \& Kotler, P. (2009). Ending poverty: “What's social marketing got to do with it?”. Social Marketing Quarterly, 15(4), 134-140.

Liu, M. T., Wong, I. A., Shi, G., Chu, R. \& Brock, J. L. (2014). The impact of corporate social responsibility (CSR) performance and perceived brand quality on customer-based brand preference. Journal of Services Marketing, 28(3), 181-194.

Makanyeza, C. and Chikazhe, L. (2017). Mediators of the relationship between service quality and customer loyalty. International Journal of Bank Marketing. https://doi.org/10.1108/IJBM-11-2016-0164

Marin, L., Ruiz, S. and Rubio, A. (2009). The role of identity salience in the effects of corporate social responsibility on consumer behaviour. Journal of business ethics, 84(1), 65-78.

Mattera, Marina, Veronica Baena, \& Julio Cervino. (2014). "Investing time wisely: enhancing brand awareness through stakeholder engagement in the service sector." International Journal of Management Practice 7, no. 2 126-143.

McDonald, R. P., \& Ho, M. H. R. (2002). Principles and practice in reporting structural $\begin{array}{llll}\text { equation analyses. } & \text { Psychological } & \text { Methods, }\end{array}$ https://doi.org/10.1037/1082-989X.7.1.64

M'zungu, Simon DM, Bill Merrilees, and Dale Miller. (2010). "Brand management to protect brand equity: A conceptual model." Journal of Brand management 17(8): 605-617.

Ng, M.N.M., (2018). The effect of service quality on student satisfaction and student loyalty: an empirical study. Journal of Social Studies Education Research, 9(3), pp.109-131.

Paulssen, M., Roulet, R. \& Wilke, S. (2014). Risk as moderator of the trust-loyalty relationship. European Journal of Marketing, 48(5, 6), 964-981.

Pratihari, S.K. \& Uzma, S.H. (2018). CSR and corporate branding effect on brand loyalty: a study on Indian banking industry. Journal of Product \& Brand Management.

Quazi, A., Amran, A. \& Nejati, M. (2016). Conceptualizing and measuring consumer social responsibility: A neglected aspect of consumer research. International journal of consumer studies, 4O(1), pp.48-56. https://doi.org/10.1111/ijcs.12211

Raizada, S. (2016). PATANJALI: Discoverer, Differentiator and Disruptor'. Business Management and Strategy, 7(2), 56-67.

Reisinger, Y. \& Mavondo, F. (2007). 'Structural equation modelling.' Journal of Travel and 
Tourism Marketing, 21(4), 41-71. 2020, Vol. 11, No. 1

Riasi, A. (2015). Competitive advantages of shadow banking industry: An analysis using Porter diamond model. Business Management and Strategy, 6(2), 15-27. DOI:0.5296/bms.v6i2.8334

Saleem, M.A., Zahra, S., Ahmad, R. and Ismail, H. (2016). Predictors of customer loyalty in the Pakistani banking industry: a moderated-mediation study. International Journal of Bank Marketing.

Sheita, A. (2019). Brand awareness in: What companies need to know?

Tingchi, Liu, M., Wong, A.I., Shi, G., Chu, R. \& Brock, J.L. (2014). The impact of corporate social responsibility (CSR) performance and perceived brand quality on customer-based brand preference. Journal of Services Marketing, 28(3), 181-194.

Trini, D., \& Salim, M. N. (2018). Customer Experience Marketing (CEM), Customer Satisfaction and Customer Trust Affects Customer Loyalty: A Study on Star Hotels in Jakarta Province. Business Management and Strategy, 9(2), 100-116. http://www.macrothink.org/journal/index.php/bms/article/download/13615/11158

Uduji, J. I., \& Okolo-Obasi, E. N. (2019). Corporate social responsibility initiatives in Nigeria and rural women livestock keepers in oil host communities. Social Responsibility Journal. https://doi.org/10.1108/SRJ-01-2018-0025

Walker, K. (2010). A systematic review of the corporate reputation literature: Definition, measurement, and theory. Corporate reputation review, 12(4), 357-387.

\section{Copyright}

Copyright for this article is retained by the author(s), with first publication rights granted to the journal.

This is an open-access article distributed under the terms and conditions of the Creative Commons Attribution license (http://creativecommons.org/licenses/by/4.0/). 